\title{
MuseoDabawenyo: An Interactive Virtual Reality Museum Application using Unity
}

\author{
Nizle Rosh H. Cabibil ${ }^{1}$, Antonio V. Lopez, Jr. ${ }^{2}$, Kezia Channen T. Obero ${ }^{3}$, Jan Carlo T. Arroyo ${ }^{4}$, \\ Allemar Jhone P. Delima ${ }^{5}$ \\ ${ }^{1-5}$ College of Computing Education, University of Mindanao, Davao City, Davao del Sur, Philippines \\ ${ }^{5}$ College of Engineering, Technology and Management, Cebu Technological University-Barili Campus, \\ Cebu, Philippines \\ nizle_cabibil@umindanao.edu.ph ${ }^{1}$, antonio_lopez@umindanao.edu.ph ${ }^{2}$, kezia_obero@umindanao.edu.ph ${ }^{3}$, \\ jancarlo_arroyo@umindanao.edu.ph ${ }^{4}$, allemarjpdjca@yahoo.com ${ }^{5}$
}

\begin{abstract}
The study aims to develop a virtual reality mobile application museum for those who are unable to visit Museo Dabawenyo in Davao City, Philippines. The virtual museum displays indigenous objects, artifacts, and old pictures of landmarks of Davao City. In this study, the three-dimensional user interface development methodology (TRES-D) was used to identify the roles, tools, and information needed for the development of the mobile app. This methodology allows a different set of tasks to be performed simultaneously during the development of the application. A 3D environment for the virtual reality museum is developed in unity. To create the digitized objects in the virtual museum, the software called Blender is used. The application allows the player to roam around the virtual museum and interact with the environment. The users are able to view information as to the object and pictures displayed within the virtual environment.
\end{abstract}

Key words: 3D technology, mobile application, Museodabawenyo, virtual reality

\section{INTRODUCTION}

Virtual reality (VR), as one of the immersive types of reality technology, is a three-dimensional computer-generated environment that can be explored and interacted with by a person. The person becomes part of the virtual world as users are able to manipulate objects and perform a series of actions depending on the features the virtual reality application has to offer.

Virtual reality simulates an experience as if the user is inside the virtual environment. VR allows users to interact with a computer-simulated environment through human sensory channels in real-time. Recently, virtual reality technology became a trend and has been enjoyed almost by the public, specifically in educational and academic communities.

A museum is a place that preserves a collection of objects or artifacts, arts, historical, cultural, or scientific importance.
Museum provides a better understanding of cultures and history. Museums are considered to be a privileged means for communication and play a central role in making history and culture accessible to the broad public.

Virtual reality is now applied in museums. One of the benefits of using advanced technology in museums is it provides a new approach to exhibit museum objects or artifacts. Besides the conventional display in the gallery, virtual reality technology offers possibilities where the objects inside the museum are digitized.

This study creates a virtual environment that highlights the selected artifacts, objects, and pictures of the chosen galleries inside the Museo Dabawenyo in Davao City, Philippines. Specifically, the study aims to develop the virtual reality environment of the museum using unity, create 3D objects inside the gallery using the blender, import and uses google cardboard SDK to implement virtual reality on the application, implement gaze-based interaction in the app using unity, and use the VR Box device for the virtual reality experience. The target users of the application are the people who cannot physically visit the site as visiting the museum in a new approach is made enjoyable by virtual reality.

\section{RELATED SYSTEMS}

2.1 Ayala Museum Virtual Tour: A Virtual Reality Application on the Android Platform

GlobeTel PH developed a virtual reality application for android devices. A $360^{\circ}$ panoramic photography based that allows the users to experience a realistic tour in Ayala Museum [1].

\subsection{Renwick Gallery WONDER 360: A Virtual Reality $360^{\circ}$ Photography-based Application}

The Smithsonian American Art Museum (SAAM) Media and Technology Office created a gallery-sized virtual reality application celebrating Renwick gallery, home to the SAAM's collection of contemporary craft [2]. 


\subsection{Cultural Centre of Delphi: A Virtual Tour Application}

The study developed an app that focuses on presenting unique sites of the European Cultural Centre of Delphi and the Museum of Delphic Festivals. The user can choose what places they would like to have a virtual tour. [3]

\subsection{A Overview of Virtual Reality Technologies}

The study tackles how virtual reality is used in the field of education. For example, ScienceSpace is a virtual reality application that focuses on education, in which the app has three different categories: PaulingWorld, NewtonWorld, and MaxwellWorld. It mainly uses HMD, which has a magnetic position tracking system for head and hands movement and displays stereoscopic images. In MaxwellWorld, the player can learn about Gauss's Law and understand its concepts while exploring electrostatic forces and fields [4].

\subsection{A Literature Review on Immersive Virtual Reality in Education: State of the Art and Perspectives}

This study reports a survey on the potentials and advantages of using Virtual Reality in Education. It shows how Virtual Reality, in general, has been mostly used in training for adults in particular situations or the students of a university [5].

\subsection{Effects of Augmented Reality and Virtual Reality on Visitor Experiences in Museum}

The study highlights the notion that advanced technologies like Augmented Reality and Virtual Reality in the museum enhance the visitor's experience. VR and AR became a massive impact on the overall visitor experience in the museum. The new technologies influenced the visitor experience that would make the tourist have an intention to revisit a museum [6].

\subsection{DynaMus: A fully Dynamic 3D Virtual Museum Framework}

According to [7], the development of technologies has reached its maturity, which enables developers to combine education with gaming. DynaMus is a web-based virtual museum framework that depends on the user's creativity. It allows users to create customized virtual galleries or exhibitions.

\section{METHODOLOGY}

\subsection{Data Gathering}

In the gathering of data, most of the information collected was from the staff of Museo Dabawenyo in Davao City, Philippines.

\subsection{Development Tools}

\subsubsection{Unity}

Unity is a game development platform designed to build Three-dimensional games. Built-in libraries let the developer allow the devices to co-interact with the application. Unity is used in the development of the virtual reality application.

\subsubsection{VR Box Headset}

A physical device that allows the user to experience virtual reality, but first, the user has to put a smartphone inside the VR Box. With this device, the users will have a virtual reality experience in taking a tour inside the virtual gallery of Museo Dabawenyo.

\subsubsection{Google Cardboard SDK for Unity}

Google Cardboard SDK allows developers to create VR experiences in the development environment of your choice. The Cardboard SDK is used to add the feature of Virtual Reality in the application.

\subsubsection{Android SDK and JDK}

The Android Software Development Kit and Java Development Kit were instrumental in the development that allows the developer to build a mobile application that is compatible with Android platforms. This SDK is used in the development of the app that is compatible with Android devices.

\subsubsection{Blender}

Blender is a three-dimensional computer graphics software that is used to create objects inside the virtual gallery. The created objects are imported in Unity Game Engine.

\subsection{Conceptual Framework}

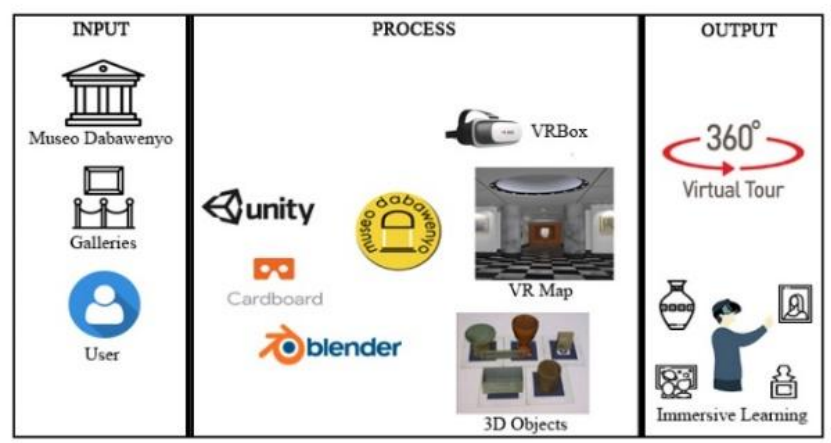

Figure 1: Conceptual framework of the application

Figure 1 illustrates how the proposed project is developed. Input data such as images of the objects and landmarks in the galleries inside Museo Dabawenyo, historical and cultural information of Davao City found in the museum, and user information are some of the data needed for the input process. For the development of the functionalities of the virtual 
reality application, the Unity which is a game engine development platform for creating the virtual environment, cardboard SDK for Unity, a VR platform that enables immersive Virtual Reality experiences, Blender which is a 3D computer graphics software for making 3D objects inside the museum, and a VRBox to let the user experience virtual reality, were used in the study. Lastly, the output of the entire process is the MuseoDabawenyo mobile application.

\section{RESULTS AND DISCUSSION}

\subsection{Functionality Test}

This section discussed the compatibility results when the app was tested on different Android-based mobile devices performed by the consultant professors from the University of Mindanao, Philippines. The results of the different tests conducted to wit: android mobile processor test, RAM test, device compatibility test, interaction test, audio compatibility test, interaction and movement test, distance test, angle test, and VR box test are shown in Tables 1-9.

Table 1: Android mobile processors test result

\begin{tabular}{|c|l|}
\hline $\begin{array}{c}\text { Android } \\
\text { CPU }\end{array}$ & Result \\
\hline $1.4 \mathrm{GHz}$ & Functions are all working, and the device performed well. \\
\hline $1.8 \mathrm{GHz}$ & Functions are all working, and the device performed well. \\
\hline $2.1 \mathrm{GHz}$ & Functions are all working, and the device performed well. \\
\hline
\end{tabular}

Table 2: Android RAM test result

\begin{tabular}{|l|l|}
\hline $\begin{array}{c}\text { Android } \\
\text { RAM }\end{array}$ & \multicolumn{1}{c|}{ Result } \\
\hline $1.5 \mathrm{~GB}$ & The application runs but experiences lag. \\
\hline $2 \mathrm{~GB}$ & The application runs smoothly. \\
\hline $3 \mathrm{~GB}$ & The application runs smoothly. \\
\hline 4GB & The application runs smoothly. \\
\hline $6 \mathrm{~GB}$ & The application runs smoothly. \\
\hline
\end{tabular}

Table 3: Android mobile device compatibility test result

\begin{tabular}{|c|c|c|}
\hline $\begin{array}{l}\text { Android } \\
\text { Device }\end{array}$ & OS & Result \\
\hline Oppo A57 & $\begin{array}{l}\text { Marshmallow } \\
6.0 .1\end{array}$ & $\begin{array}{l}\text { The performance of the device is good. } \\
\text { The device may experience a delay } \\
\text { compared to other devices, but still, all } \\
\text { functions are working. }\end{array}$ \\
\hline $\begin{array}{l}\text { Samsung } \\
\text { Galaxy S6 }\end{array}$ & Nougat 7.0 & $\begin{array}{l}\text { The device performs well, and all } \\
\text { functions are working. }\end{array}$ \\
\hline $\begin{array}{l}\text { Xiaomi } \\
\text { Redmi } \\
\text { Note } 3\end{array}$ & $\begin{array}{c}\text { Marshmallow } \\
6.0\end{array}$ & $\begin{array}{l}\text { The device performs but experiences a } \\
\text { bit of delay from time to time, but all } \\
\text { functions are still working. }\end{array}$ \\
\hline $\begin{array}{l}\text { Asus } \\
\text { Zenfone } \\
\text { Max }\end{array}$ & $\begin{array}{l}\text { Marshmallow } \\
\quad 6.0\end{array}$ & $\begin{array}{l}\text { The device performs well, and all } \\
\text { functions are working. }\end{array}$ \\
\hline $\begin{array}{l}\text { Samsung } \\
\text { Galaxy } \\
\text { Note } 4\end{array}$ & $\begin{array}{l}\text { Marshmallow } \\
\quad 6.0\end{array}$ & $\begin{array}{l}\text { The device performs well, and all } \\
\text { functions are working. }\end{array}$ \\
\hline $\begin{array}{l}\text { Samsung } \\
\text { Galaxy S7 } \\
\text { Edge }\end{array}$ & $\begin{array}{l}\text { Marshmallow } \\
6.0\end{array}$ & $\begin{array}{l}\text { The device performs well, and all } \\
\text { functions are working. }\end{array}$ \\
\hline $\begin{array}{l}\text { Asus } \\
\text { Zenfone 5z }\end{array}$ & 9.0 & $\begin{array}{l}\text { The device performs well, and all } \\
\text { functions are working. }\end{array}$ \\
\hline $\begin{array}{l}\text { Xiaomi } \\
\text { POCO F1 }\end{array}$ & 9.0 & $\begin{array}{l}\text { The device performs well, and all } \\
\text { functions are working. }\end{array}$ \\
\hline $\begin{array}{l}\text { Huawei } \\
\text { Nova } 3 \mathrm{i}\end{array}$ & 8.1 Oreo & $\begin{array}{l}\text { The device performs well, and all } \\
\text { functions are working. }\end{array}$ \\
\hline $\begin{array}{l}\text { Samsung } \\
\text { Galaxy } \\
\text { A50 }\end{array}$ & 9.0 Pie & $\begin{array}{l}\text { The device performs well, and all } \\
\text { functions are working. }\end{array}$ \\
\hline
\end{tabular}

Table 4: Interaction (movement) test result

\begin{tabular}{|c|c|c|c|}
\hline $\begin{array}{l}\text { Android } \\
\text { Device }\end{array}$ & Function & OS & Result \\
\hline Oppo A57 & $\begin{array}{l}\text { Moving } \\
\text { around the } \\
\text { gallery } \\
\text { Choosing } \\
\text { Gallery in } \\
\text { Main Menu }\end{array}$ & $\begin{array}{l}\text { Marshmallow } \\
6.0 .1\end{array}$ & $\begin{array}{l}\text { The device experience a } \\
\text { bit of movement delay, } \\
\text { but the functions are still } \\
\text { working. }\end{array}$ \\
\hline $\begin{array}{l}\text { Samsung } \\
\text { Galaxy S6 }\end{array}$ & $\begin{array}{l}\text { Moving } \\
\text { around the } \\
\text { gallery } \\
\text { Choosing } \\
\text { Gallery in } \\
\text { Main Menu }\end{array}$ & Nougat 7.0 & $\begin{array}{l}\text { The application runs } \\
\text { smoothly without any } \\
\text { movement delay, and the } \\
\text { functions are working. }\end{array}$ \\
\hline $\begin{array}{l}\text { Xiaomi } \\
\text { Redmi } \\
\text { Note } 3\end{array}$ & $\begin{array}{l}\text { Moving } \\
\text { around the } \\
\text { gallery } \\
\text { Choosing } \\
\text { Gallery in } \\
\text { Main Menu }\end{array}$ & $\begin{array}{l}\text { Marshmallow } \\
6.0\end{array}$ & $\begin{array}{l}\text { The application runs } \\
\text { with a bit of delay from } \\
\text { time to time, but still, all } \\
\text { functions are working. }\end{array}$ \\
\hline $\begin{array}{l}\text { Asus } \\
\text { Zenfone } \\
\text { Max }\end{array}$ & $\begin{array}{l}\text { Moving } \\
\text { around the } \\
\text { gallery } \\
\text { Choosing } \\
\text { Gallery in } \\
\text { Main Menu }\end{array}$ & $\begin{array}{l}\text { Marshmallow } \\
6.0\end{array}$ & $\begin{array}{l}\text { The application runs } \\
\text { smoothly without any } \\
\text { movement delay, and the } \\
\text { functions are working. }\end{array}$ \\
\hline $\begin{array}{l}\text { Samsung } \\
\text { Galaxy } \\
\text { Note } 4\end{array}$ & $\begin{array}{l}\text { Moving } \\
\text { around the } \\
\text { gallery } \\
\text { Choosing } \\
\text { Gallery in } \\
\text { Main Menu }\end{array}$ & $\begin{array}{l}\text { Marshmallow } \\
6.0\end{array}$ & $\begin{array}{l}\text { The application runs } \\
\text { smoothly without any } \\
\text { movement delay, and the } \\
\text { functions are working. }\end{array}$ \\
\hline $\begin{array}{l}\text { Samsung } \\
\text { Galaxy S7 } \\
\text { Edge }\end{array}$ & $\begin{array}{l}\text { Moving } \\
\text { around the } \\
\text { gallery } \\
\text { Choosing } \\
\text { Gallery in } \\
\text { Main Menu }\end{array}$ & $\begin{array}{l}\text { Marshmallow } \\
6.0\end{array}$ & $\begin{array}{l}\text { The application runs } \\
\text { smoothly without any } \\
\text { movement delay, and the } \\
\text { functions are working. }\end{array}$ \\
\hline $\begin{array}{l}\text { Asus } \\
\text { Zenfone } \\
5 z\end{array}$ & $\begin{array}{l}\text { Moving } \\
\text { around the } \\
\text { gallery } \\
\text { Choosing } \\
\text { Gallery in } \\
\text { Main Menu }\end{array}$ & 9.0 & $\begin{array}{l}\text { The application runs } \\
\text { smoothly without any } \\
\text { movement delay, and the } \\
\text { functions are working. }\end{array}$ \\
\hline $\begin{array}{l}\text { Xiaomi } \\
\text { POCO F1 }\end{array}$ & $\begin{array}{l}\text { Moving } \\
\text { around the } \\
\text { gallery } \\
\text { Choosing } \\
\text { Gallery in } \\
\text { Main Menu }\end{array}$ & 9.0 & $\begin{array}{l}\text { The application runs } \\
\text { smoothly, and the } \\
\text { functions are working. }\end{array}$ \\
\hline $\begin{array}{l}\text { Huawei } \\
\text { Nova 3i }\end{array}$ & $\begin{array}{l}\text { Moving } \\
\text { around the } \\
\text { gallery } \\
\text { Choosing } \\
\text { Gallery in } \\
\text { Main Menu }\end{array}$ & 8.1 Oreo & $\begin{array}{l}\text { The application runs } \\
\text { smoothly, and the } \\
\text { functions are working. }\end{array}$ \\
\hline $\begin{array}{l}\text { Samsung } \\
\text { Galaxy } \\
\text { A50 }\end{array}$ & $\begin{array}{l}\text { Moving } \\
\text { around the } \\
\text { gallery } \\
\text { Choosing } \\
\text { Gallery in } \\
\text { Main Menu }\end{array}$ & 9.0 Pie & $\begin{array}{l}\text { The application runs } \\
\text { smoothly, and the } \\
\text { functions are working. }\end{array}$ \\
\hline
\end{tabular}


Table 5: Audio compatibility test result

\begin{tabular}{|c|c|c|}
\hline $\begin{array}{c}\text { Android } \\
\text { Mobile }\end{array}$ & Speaker & Headphone \\
\hline Oppo A57 & $\begin{array}{l}\text { The speakers have to } \\
\text { be on full volume to } \\
\text { have better music } \\
\text { experience. }\end{array}$ & $\begin{array}{l}\text { The volume does not have to be } \\
\text { on full, and the user can adjust } \\
\text { the volume to their preference } \\
\text { until they can hear the audio. }\end{array}$ \\
\hline $\begin{array}{l}\text { Samsung } \\
\text { Galaxy S6 }\end{array}$ & $\begin{array}{l}\text { The speakers have to } \\
\text { be on full volume to } \\
\text { have better music } \\
\text { experience. }\end{array}$ & $\begin{array}{l}\text { The volume does not have to be } \\
\text { on full, and the user can adjust } \\
\text { the volume to their preference } \\
\text { until they can hear the audio. }\end{array}$ \\
\hline $\begin{array}{l}\text { Xiaomi } \\
\text { Redmi } \\
\text { Note } 3\end{array}$ & $\begin{array}{l}\text { The speakers have to } \\
\text { be on full volume to } \\
\text { have better music } \\
\text { experience. }\end{array}$ & $\begin{array}{l}\text { The volume does not have to be } \\
\text { on full, and the user can adjust } \\
\text { the volume to their preference } \\
\text { until they can hear the audio. }\end{array}$ \\
\hline $\begin{array}{l}\text { Asus } \\
\text { Zenfone } \\
\text { Max }\end{array}$ & $\begin{array}{l}\text { The speakers have to } \\
\text { be on full volume to } \\
\text { have better music } \\
\text { experience. }\end{array}$ & $\begin{array}{l}\text { The volume does not have to be } \\
\text { on full, and the user can adjust } \\
\text { the volume to their preference } \\
\text { until they can hear the audio. }\end{array}$ \\
\hline $\begin{array}{l}\text { Samsung } \\
\text { Galaxy } \\
\text { Note } 4\end{array}$ & $\begin{array}{l}\text { The speakers have to } \\
\text { be on full volume to } \\
\text { have better music } \\
\text { experience. }\end{array}$ & $\begin{array}{l}\text { The volume does not have to be } \\
\text { on full, and the user can adjust } \\
\text { the volume to their preference } \\
\text { until they can hear the audio. }\end{array}$ \\
\hline $\begin{array}{l}\text { Samsung } \\
\text { Galaxy S7 } \\
\text { Edge }\end{array}$ & $\begin{array}{l}\text { The speakers have to } \\
\text { be on full volume to } \\
\text { have better music } \\
\text { experience. }\end{array}$ & $\begin{array}{l}\text { The volume does not have to be } \\
\text { on full, and the user can adjust } \\
\text { the volume to their preference } \\
\text { until they can hear the audio. }\end{array}$ \\
\hline $\begin{array}{l}\text { Asus } \\
\text { Zenfone } \\
5 z\end{array}$ & $\begin{array}{l}\text { The speakers have to } \\
\text { be on full volume to } \\
\text { have better music } \\
\text { experience. }\end{array}$ & $\begin{array}{l}\text { The volume does not have to be } \\
\text { on full, and the user can adjust } \\
\text { the volume to their preference } \\
\text { until they can hear the audio. }\end{array}$ \\
\hline $\begin{array}{l}\text { Xiaomi } \\
\text { POCO F1 }\end{array}$ & $\begin{array}{l}\text { The speakers have to } \\
\text { be on full volume to } \\
\text { have better music } \\
\text { experience. }\end{array}$ & $\begin{array}{l}\text { The volume does not have to be } \\
\text { on full, and the user can adjust } \\
\text { the volume to their preference } \\
\text { until they can hear the audio. }\end{array}$ \\
\hline $\begin{array}{l}\text { Huawei } \\
\text { Nova 3i }\end{array}$ & $\begin{array}{l}\text { The speakers have to } \\
\text { be on full volume to } \\
\text { have better music } \\
\text { experience. }\end{array}$ & $\begin{array}{l}\text { The volume does not have to be } \\
\text { on full, and the user can adjust } \\
\text { the volume to their preference } \\
\text { until they can hear the audio. }\end{array}$ \\
\hline $\begin{array}{l}\text { Samsung } \\
\text { Galaxy } \\
\text { A50 }\end{array}$ & $\begin{array}{l}\text { The speakers have to } \\
\text { be on full volume to } \\
\text { have better music } \\
\text { experience. }\end{array}$ & $\begin{array}{l}\text { The volume does not have to be } \\
\text { on full, and the user can adjust } \\
\text { the volume to their preference } \\
\text { until they can hear the audio. }\end{array}$ \\
\hline
\end{tabular}

\begin{tabular}{|c|c|c|c|}
\hline & $\begin{array}{l}\text { interaction on an } \\
\text { object/artifact }\end{array}$ & & \\
\hline $\begin{array}{l}\text { Asus } \\
\text { Zenfone } \\
\text { Max }\end{array}$ & $\begin{array}{l}\text { - Moving around } \\
\text { the gallery } \\
\text { - Choosing } \\
\text { Gallery in Main } \\
\text { Menu } \\
\text { - Gaze } \\
\text { interaction on an } \\
\text { object/artifact }\end{array}$ & $\begin{array}{l}\text { All } \\
\text { functions } \\
\text { will work } \\
\text { well }\end{array}$ & $\begin{array}{l}\text { The application runs } \\
\text { smoothly without any } \\
\text { movement delay, and } \\
\text { the functions are } \\
\text { working. }\end{array}$ \\
\hline $\begin{array}{l}\text { Samsung } \\
\text { Galaxy } \\
\text { Note } 4\end{array}$ & $\begin{array}{l}\text { - Moving around } \\
\text { the gallery } \\
\text { - Choosing } \\
\text { Gallery in Main } \\
\text { Menu } \\
\text { - Gaze } \\
\text { interaction on an } \\
\text { object/artifact }\end{array}$ & $\begin{array}{l}\text { All } \\
\text { functions } \\
\text { will work } \\
\text { well }\end{array}$ & $\begin{array}{l}\text { The application runs } \\
\text { smoothly without any } \\
\text { movement delay, and } \\
\text { the functions are } \\
\text { working. }\end{array}$ \\
\hline $\begin{array}{l}\text { Samsung } \\
\text { Galaxy } \\
\text { S7 Edge }\end{array}$ & $\begin{array}{l}\text { - Moving around } \\
\text { the gallery } \\
\text { - Choosing } \\
\text { Gallery in Main } \\
\text { Menu } \\
\text { - Gaze } \\
\text { interaction on an } \\
\text { object/artifact }\end{array}$ & $\begin{array}{l}\text { All } \\
\text { functions } \\
\text { will work } \\
\text { well }\end{array}$ & $\begin{array}{l}\text { The application runs } \\
\text { smoothly without any } \\
\text { movement delay, and } \\
\text { the functions are } \\
\text { working. }\end{array}$ \\
\hline $\begin{array}{l}\text { Asus } \\
\text { Zenfone } \\
5 z\end{array}$ & $\begin{array}{l}\text { - Moving around } \\
\text { the gallery } \\
\text { - Choosing } \\
\text { Gallery in Main } \\
\text { Menu } \\
\text { - Gaze } \\
\text { interaction on an } \\
\text { object/artifact }\end{array}$ & $\begin{array}{l}\text { All } \\
\text { functions } \\
\text { will work } \\
\text { well }\end{array}$ & $\begin{array}{l}\text { The application runs } \\
\text { smoothly without any } \\
\text { movement delay, and } \\
\text { the functions are } \\
\text { working. }\end{array}$ \\
\hline $\begin{array}{l}\text { Xiaomi } \\
\text { POCO } \\
\text { F1 }\end{array}$ & $\begin{array}{l}\text { - Moving around } \\
\text { the gallery } \\
\text { - Choosing } \\
\text { Gallery in Main } \\
\text { Menu }\end{array}$ & $\begin{array}{l}\text { All } \\
\text { functions } \\
\text { will work } \\
\text { well }\end{array}$ & $\begin{array}{l}\text { The application runs } \\
\text { smoothly, and the } \\
\text { functions are working. }\end{array}$ \\
\hline $\begin{array}{l}\text { Huawei } \\
\text { Nova 3i }\end{array}$ & $\begin{array}{l}\text { - Moving around } \\
\text { the gallery } \\
\text { - Choosing } \\
\text { Gallery in Main } \\
\text { Menu } \\
\text { - Gaze } \\
\text { interaction on an } \\
\text { object/artifact }\end{array}$ & $\begin{array}{l}\text { All } \\
\text { functions } \\
\text { will work } \\
\text { well }\end{array}$ & $\begin{array}{l}\text { The application runs } \\
\text { smoothly, and the } \\
\text { functions are working. }\end{array}$ \\
\hline $\begin{array}{l}\text { Samsung } \\
\text { Galaxy } \\
\text { A50 }\end{array}$ & $\begin{array}{l}\text { - Moving around } \\
\text { the gallery } \\
\text { - Choosing } \\
\text { Gallery in Main } \\
\text { Menu } \\
\text { - Gaze } \\
\text { interaction on an } \\
\text { object/artifact }\end{array}$ & $\begin{array}{l}\text { All } \\
\text { functions } \\
\text { will work } \\
\text { well }\end{array}$ & $\begin{array}{l}\text { The application runs } \\
\text { smoothly, and the } \\
\text { functions are working. }\end{array}$ \\
\hline
\end{tabular}

Table 6: Module testing test result - interaction and movement

\begin{tabular}{|c|c|c|c|}
\hline $\begin{array}{c}\text { Android } \\
\text { Device }\end{array}$ & Functions & $\begin{array}{c}\text { Expected } \\
\text { Result }\end{array}$ & Actual Result \\
\hline $\begin{array}{l}\text { Oppo } \\
\text { A57 }\end{array}$ & $\begin{array}{l}\text { - Moving around } \\
\text { the gallery } \\
\text { - Choosing } \\
\text { Gallery in Main } \\
\text { Menu } \\
\text { - Gaze } \\
\text { interaction on an } \\
\text { object/artifact }\end{array}$ & $\begin{array}{l}\text { All } \\
\text { functions } \\
\text { will work } \\
\text { well }\end{array}$ & $\begin{array}{l}\text { The device experience } \\
\text { a bit of movement } \\
\text { delay, but the functions } \\
\text { are still working. }\end{array}$ \\
\hline $\begin{array}{l}\text { Samsung } \\
\text { Galaxy } \\
\text { S6 }\end{array}$ & $\begin{array}{l}\text { - Moving around } \\
\text { the gallery } \\
\text { - Choosing } \\
\text { Gallery in Main } \\
\text { Menu } \\
\text { - Gaze } \\
\text { interaction on an } \\
\text { object/artifact }\end{array}$ & $\begin{array}{l}\text { All } \\
\text { functions } \\
\text { will work } \\
\text { well }\end{array}$ & $\begin{array}{l}\text { The application runs } \\
\text { smoothly without any } \\
\text { movement delay, and } \\
\text { the functions are } \\
\text { working. }\end{array}$ \\
\hline $\begin{array}{l}\text { Xiaomi } \\
\text { Redmi } \\
\text { Note } 3\end{array}$ & $\begin{array}{l}\text { - Moving around } \\
\text { the gallery } \\
\text { - Choosing } \\
\text { Gallery in Main } \\
\text { Menu } \\
\text { - Gaze }\end{array}$ & $\begin{array}{l}\text { All } \\
\text { functions } \\
\text { will work } \\
\text { well }\end{array}$ & $\begin{array}{l}\text { The application runs } \\
\text { with a bit of delay from } \\
\text { time to time, but still, } \\
\text { all functions are } \\
\text { working. }\end{array}$ \\
\hline
\end{tabular}


Table 7: Distance test result

\begin{tabular}{|l|l|l|}
\hline \multicolumn{1}{|c|}{ Distance } & \multicolumn{1}{|c|}{ Objective } & \multicolumn{1}{c|}{ Result } \\
\hline $\begin{array}{l}0.5 \text { meter away } \\
\text { from the } \\
\text { information } \\
\text { canvas }\end{array}$ & $\begin{array}{l}\text { The user can able to } \\
\text { read the text in the } \\
\text { information box. }\end{array}$ & $\begin{array}{l}\text { The user sees the text on } \\
\text { the information canvas. }\end{array}$ \\
\hline $\begin{array}{l}1 \text { meter away } \\
\text { from the } \\
\text { canvasmation }\end{array}$ & $\begin{array}{l}\text { The user can able to } \\
\text { read the text in the } \\
\text { information box. }\end{array}$ & $\begin{array}{l}\text { The user sees the text on } \\
\text { the information canvas. }\end{array}$ \\
\hline $\begin{array}{l}1.5 \text { meters away } \\
\text { from } \\
\text { information the } \\
\text { canvas }\end{array}$ & $\begin{array}{l}\text { The user can able to } \\
\text { read the text in the } \\
\text { information box. }\end{array}$ & $\begin{array}{l}\text { The user sees the text on } \\
\text { the information canvas } \\
\text { but somehow unreadable. }\end{array}$ \\
\hline $\begin{array}{l}2 \text { meters away } \\
\text { from } \\
\text { information } \\
\text { canvas }\end{array}$ & $\begin{array}{l}\text { The user can able to } \\
\text { read the text in the } \\
\text { information box. }\end{array}$ & $\begin{array}{l}\text { The user sees the text on } \\
\text { the information canvas } \\
\text { but unreadable. }\end{array}$ \\
\hline
\end{tabular}

Table 8. Angle test result

\begin{tabular}{|l|l|l|}
\hline \multicolumn{1}{|c|}{ Angle/Degree } & \multicolumn{1}{|c|}{ Objective } & \multicolumn{1}{c|}{ Result } \\
\hline $\begin{array}{l}\text { degrees (Left or } \\
\text { Right) X-axis }\end{array}$ & $\begin{array}{l}\text { The user can move } \\
\text { left or right. }\end{array}$ & $\begin{array}{l}\text { The said objective was to } \\
\text { accomplish. The user was } \\
\text { able to turn left or right. }\end{array}$ \\
\hline $\begin{array}{l}\text { Y-axis } \\
\text { Tegrees } \\
\text { degree - 45 }\end{array}$ & $\begin{array}{l}\text { The user can detect } \\
\text { the artifact when the } \\
\text { character is facing the } \\
\text { specific object }\end{array}$ & $\begin{array}{l}\text { The stated objective was } \\
\text { accomplished, but if the } \\
\text { user is in a 30 degrees - 45 } \\
\text { degrees position, the } \\
\text { information } \\
\text { becomes vague. }\end{array}$ \\
\hline $\begin{array}{l}\text { degree canvas } \\
\text { degrees X-axis }\end{array}$ & $\begin{array}{l}\text { The user can turn } \\
\text { around. }\end{array}$ & $\begin{array}{l}\text { The objective has been } \\
\text { met. }\end{array}$ \\
\hline $\begin{array}{l}\text { degree - 350 } \\
\text { degrees X-axis } \\
\text { and Y-axis }\end{array}$ & $\begin{array}{l}\text { The user can fully } \\
\text { rotate. }\end{array}$ & $\begin{array}{l}\text { The said objective has } \\
\text { been met, and the user } \\
\text { was able to rotate at a full } \\
\text { 350 degrees. }\end{array}$ \\
\hline
\end{tabular}

Table 9: VR box test result

\begin{tabular}{|c|c|c|c|}
\hline $\begin{array}{c}\text { Android } \\
\text { Device }\end{array}$ & Dimensions & $\begin{array}{c}\text { 3D Glasses } \\
\text { Device }\end{array}$ & Result \\
\hline Oppo A57 & $\begin{array}{l}5.87 \times 2.87 \\
\text { inches }\end{array}$ & $\begin{array}{l}\text { VR Box } \\
\text { Dimensions: } 6.50 \\
x 3.50 \text { inches }\end{array}$ & $\begin{array}{l}\text { The phone fits } \\
\text { perfectly with } \\
\text { the device. } \\
\text { The user does } \\
\text { not need to } \\
\text { adjust the lens } \\
\text { to have the best } \\
\text { VR experience. }\end{array}$ \\
\hline $\begin{array}{l}\text { Samsung } \\
\text { Galaxy S6 }\end{array}$ & $\begin{array}{l}5.65 \times 2.78 \\
\text { inches }\end{array}$ & $\begin{array}{l}\text { VR Box } \\
\text { Dimensions: } 6.50 \\
x 3.50 \text { inches }\end{array}$ & $\begin{array}{l}\text { The phone fits } \\
\text { perfectly with } \\
\text { the device. } \\
\text { The user does } \\
\text { not need to } \\
\text { adjust the lens } \\
\text { to have the best } \\
\text { VR experience. }\end{array}$ \\
\hline $\begin{array}{l}\text { Xiaomi Redmi } \\
\text { Note } 3\end{array}$ & $\begin{array}{l}5.91 \times 2.99 \\
\text { inches }\end{array}$ & $\begin{array}{l}\text { VR Box } \\
\text { Dimensions: } 6.50 \\
x 3.50 \text { inches }\end{array}$ & $\begin{array}{l}\text { The phone fits } \\
\text { the device, but } \\
\text { the power } \\
\text { button } \\
\text { pressed. } \\
\text { The user does } \\
\text { not need to } \\
\text { adjust the lens a } \\
\text { little bit to make } \\
\text { to have the best } \\
\text { VR experience. }\end{array}$ \\
\hline Asus Zenfone & $\begin{array}{l}6.14 \times 3.05 \\
\text { inches }\end{array}$ & $\begin{array}{ll}\text { VR } & \text { Box } \\
\text { Dimensions: } & 6.50\end{array}$ & $\begin{array}{l}\text { The phone fits } \\
\text { the device, but }\end{array}$ \\
\hline
\end{tabular}

\begin{tabular}{|c|c|c|c|}
\hline Max & & x 3.50 inches & $\begin{array}{l}\text { the power } \\
\text { button is } \\
\text { pressed. } \\
\text { The user needs } \\
\text { to adjust the } \\
\text { lens to have the } \\
\text { best VR } \\
\text { experience. }\end{array}$ \\
\hline $\begin{array}{l}\text { Samsung } \\
\text { Galaxy Note } 4\end{array}$ & $\begin{array}{l}6.04 \times 3.09 \\
\text { inches }\end{array}$ & $\begin{array}{l}\text { VR Box } \\
\text { Dimensions: } 6.50 \\
\text { x } 3.50 \text { inches }\end{array}$ & $\begin{array}{l}\text { The phone fits } \\
\text { the device. } \\
\text { The user needs } \\
\text { to adjust the } \\
\text { lens to have the } \\
\text { best VR } \\
\text { experience. }\end{array}$ \\
\hline $\begin{array}{l}\text { Samsung } \\
\text { Galaxy } \quad \text { S7 } \\
\text { Edge }\end{array}$ & $\begin{array}{l}5.94 \times 2.86 \\
\text { inches }\end{array}$ & $\begin{array}{l}\text { VR Box } \\
\text { Dimensions: } 6.50 \\
\text { x } 3.50 \text { inches }\end{array}$ & $\begin{array}{l}\text { The phone fits } \\
\text { the device. } \\
\text { The user does } \\
\text { not need to } \\
\text { adjust the lens } \\
\text { to have the best } \\
\text { VR experience. }\end{array}$ \\
\hline $\begin{array}{l}\text { Asus Zenfone } \\
5 z\end{array}$ & $\begin{array}{l}6.02 \times 2.98 \\
\text { inches }\end{array}$ & $\begin{array}{l}\text { VR } \quad \text { Box } \\
\text { Dimensions: } 6.50 \\
x 3.50 \text { inches }\end{array}$ & $\begin{array}{l}\text { The phone fits } \\
\text { the device, but } \\
\text { the power } \\
\text { button is } \\
\text { pressed. } \\
\text { We need little } \\
\text { adjustments to } \\
\text { the lens to have } \\
\text { the best VR } \\
\text { experience. }\end{array}$ \\
\hline $\begin{array}{l}\text { Xiaomi POCO } \\
\text { F1 }\end{array}$ & $\begin{array}{l}6.12 \times 2.96 \\
\text { inches }\end{array}$ & $\begin{array}{l}\text { VR Box } \\
\text { Dimensions: } 6.50 \\
\text { x } 3.50 \text { inches }\end{array}$ & $\begin{array}{l}\text { The phone fits } \\
\text { the device. } \\
\text { Needs } \\
\text { adjustments to } \\
\text { the lens to have } \\
\text { the best VR } \\
\text { experience. }\end{array}$ \\
\hline $\begin{array}{l}\text { Huawei Nova } \\
3 \mathrm{i}\end{array}$ & $\begin{array}{l}6.20 \times 2.96 \\
\text { inches }\end{array}$ & $\begin{array}{l}\text { VR } \quad \text { Box } \\
\text { Dimensions: } 6.50 \\
\text { x } 3.50 \text { inches }\end{array}$ & $\begin{array}{l}\text { The phone fits } \\
\text { the device, but } \\
\text { the power } \\
\text { button is } \\
\text { pressed. } \\
\text { Needs } \\
\text { adjustments to } \\
\text { the lens to have } \\
\text { the best VR } \\
\text { experience. }\end{array}$ \\
\hline $\begin{array}{l}\text { Samsung } \\
\text { Galaxy A50 }\end{array}$ & $\begin{array}{l}6.24 \times 2.94 \\
\text { inches }\end{array}$ & $\begin{array}{l}\text { VR Box } \\
\text { Dimensions: } 6.50 \\
\text { x } 3.50 \text { inches }\end{array}$ & $\begin{array}{l}\text { The phone fits } \\
\text { the device, but } \\
\text { the power } \\
\text { button is } \\
\text { pressed. } \\
\text { Needs } \\
\text { adjustments to } \\
\text { the lens to have } \\
\text { the best VR } \\
\text { experience. }\end{array}$ \\
\hline
\end{tabular}

The result revealed the minimum required specifications of the mobile devices to be used to run the application after testing the virtual reality application on different versions of android smartphones. A device with the minimum specifications of 720x1280 pixels of screen resolution having $1.4 \mathrm{GHz} \mathrm{CPU}$ and $1.5 \mathrm{G} \mathrm{RAM}$ is required to run the system. However, such devices must have a gyroscope sensor to be 
used for navigation. The gyroscope sensor detects head movement that enables a player to interact inside a virtual environment.

\subsection{Gameplay}

The 3D objects, pictures, and VR environment are realistic from the perspective of the player. Figures 2-7 show some of the perceived graphics when using the application.

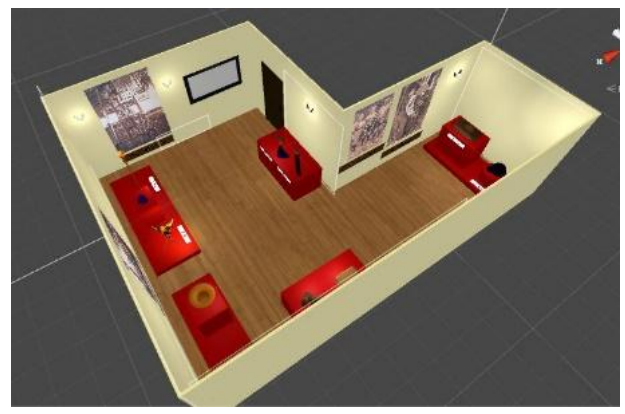

Figure 2: Lumadnog gallery

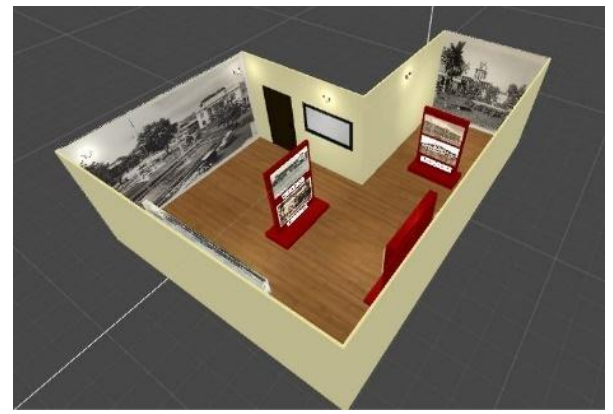

Figure 3: Duhwow, Dabaw, Davao gallery

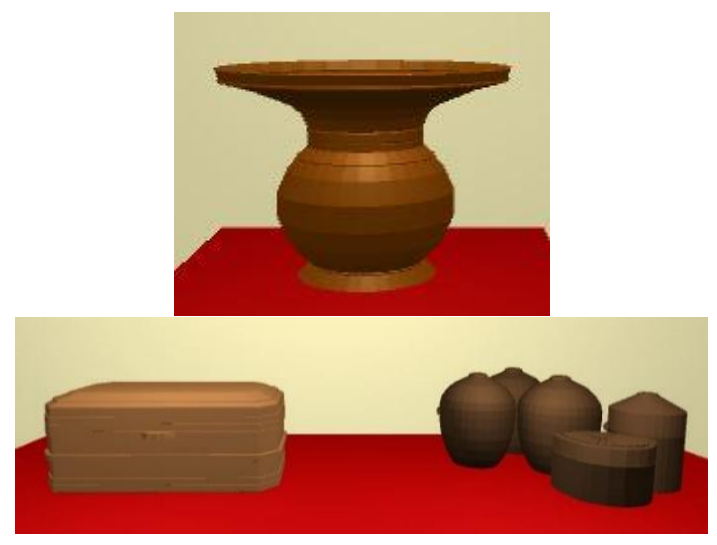

Figure 4: 3D objects

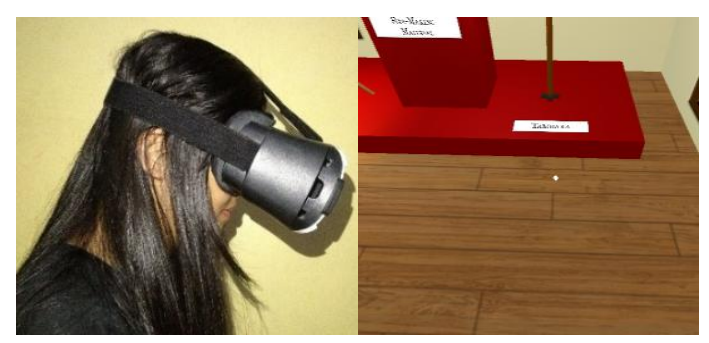

Figure 5: 3D environment 1

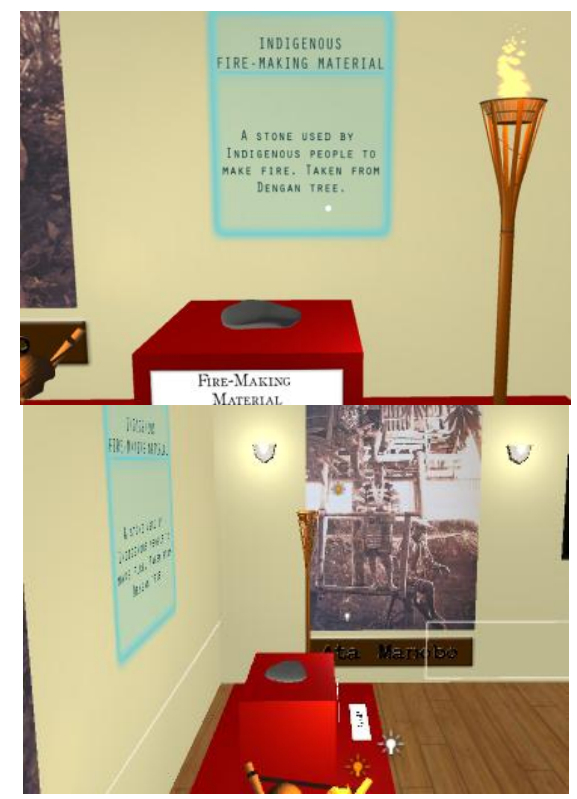

Figure 6: $3 \mathrm{D}$ environment 2

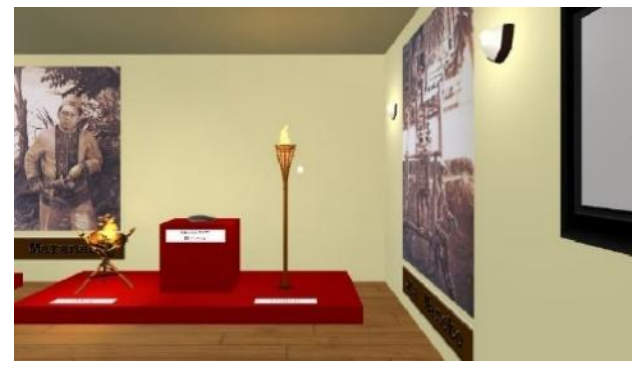

Figure 7: 3D environment 3

\section{CONCLUSION}

This study developed a virtual reality application that runs on android devices that has a gyroscope sensor. It can be concluded that all the requirements specified in creating the interactive virtual reality museum mobile application were completed. The objectives of the study are met, as evident in the evaluation results after various testing was conducted.

\section{REFERENCES}

[1] GlobeTel PH (2015, March). Ayala Museum Virtual Tour: A virtual reality application on the Android platform. Retrieved February 13, 2018, from https://play.google.com/store/apps/details?id=com.y ondu.ayalamuseumcardboard \&hl=en

Smithsonian American Art Museum (SAAM) Media and Technology Office (2016, August). Renwick Gallery WONDER 360: A virtual reality $360^{\circ}$ Photography based application. Retrieved February 13, 2018, from

https://play.google.com/store/apps/details?id=edu.si .americanart.wonder 360

[3] Tool Ltd. (2016, February). Cultural Centre of Delphi: A virtual tour application. Retrieved February 13, 2018, from 
https://play.google.com/store/apps/details?id=gr.too 1.eccd

[4] Yuri Antonio Goncalves Vilas Boas (2013). Overview of Virtual Reality Technologies.Retrieved February 13, 2018, from https://pdfs.semanticscholar.org/4214/cb09e29795f 5363e5e3b545750dce027b668.pdf

[5] Michela Ott, Laura Freina (2015).A Literature Review on Immersive Virtual Reality in Education: State of the Art and Perspectives. Retrieved February 13, 2018, from https://www.ceeol.com/se arch/articledetail? id=289829

[6] T. Jung, M. Claudia, T. Dieck, H. Lee, and N. (2016, January). Effects of Virtual Reality and Augmented Reality on Visitor Experiences in Museum. Retrieved February 13, 2018, from https://link.springer.com/chapte r/10.1007/978-3-319-28231-2_45

[7] C. Kiourt, A. Kousoudis, and G. Pavlidis (2016, December). DynaMus: A fully Dynamic 3D Virtual Museum Framework. Retrieved February 13, 2018, from https://www.sciencedirect.com/science/articl e/pii/S1296207416301029

https://doi.org/10.1016/j.culher.2016.06.007 